\title{
Establishing a new mouse model for investigating the function of amygdala neurons in anxiety Yvan Peterschmitt ${ }^{1,2}$, Stefan Weger ${ }^{3}$, Alexander Plauth ${ }^{3}$, Regine Heilbronn ${ }^{3}$, William Wisden ${ }^{4}$, Günther Sperk ${ }^{1}$ and Werner Sieghart*2
}

\author{
Address: ${ }^{1}$ Institute of Pharmacology, Medical University of Innsbruck, 6020 Innsbruck, Austria, ${ }^{2}$ Center for Brain Research, Medical University of \\ Vienna, 1090 Vienna, Austria, ${ }^{3}$ Institute of Virology, Charité Centrum, Medical University of Berlin, 12203 Berlin, Germany and ${ }^{4}$ Institute of \\ Medical Sciences, University of Aberdeen, Foresterhill, Aberdeen, AB25 2ZD, UK \\ Email: Werner Sieghart* - werner.sieghart@meduniwien.ac.at \\ * Corresponding author
}

from I4th Scientific Symposium of the Austrian Pharmacological Society (APHAR)

Innsbruck, Austria. 21-22 November 2008

Published: 5 November 2008

BMC Pharmacology 2008, 8(Suppl I):A35 doi:I0.II86/I47I-22I0-8-SI-A35

This abstract is available from: http://www.biomedcentral.com/I47I-22I 0/8/SI/A35

(c) 2008 Peterschmitt et al; licensee BioMed Central Ltd.

Benzodiazepine site agonists modulate the firing pattern of neurons via $\mathrm{GABA}_{\mathrm{A}}$ receptors and by that influence the activity of the network in which they participate and cause appropriate changes in behaviour. Since the amygdala is involved in regulating anxiety, it can be expected that $\mathrm{GABA}_{\mathrm{A}}$ receptors located in this brain region contribute to the anxiolytic effects of benzodiazepine site agonists. Here we take advantage of an in vivo mouse model [1] in which a Phe to Ile point mutation was introduced into the gene coding for the $\mathrm{GABA}_{\mathrm{A}}$ receptor $\gamma 2$ subunit. This $\gamma 2 \mathrm{~F} 77 \mathrm{I}$ mutation, which was also flanked by loxP sites, affects only the benzodiazepine binding site of the respective receptors, and mice carrying this mutation no longer are sensitive to certain benzodiazepine site agonists but are otherwise normal. Here we aim to selectively replace the "benzodiazepine insensitive" mutated $\gamma 2$ F77I subunit by a GFP-labeled native one in the amygdala of $\gamma 2$ F77Ilox mice by a stereotaxic injection of recombinant adenoassociated viral (rAAV) vectors expressing Cre-recombinase and GFP-labeled wild-type $\gamma 2$ subunits. It has been demonstrated previously that the replaced wild-type subunits combine with endogenous subunits to form completely assembled receptors with normal subcellular distribution. Then only those amygdala neurons expressing the GFP-labeled wild-type $\gamma 2$ subunits can be modulated by a systemic application of these benzodiazepine site agonists and any behavioural effects observed with these drugs must have been generated via these neurons. In this report we present a preliminary characterization of the newly developed mouse model demonstrating the correct expression of Cre-recombinase and GFP-labeled wild-type $\gamma 2$ subunits in amygdala neurons by immunohistochemical and in situ hybridization techniques. Future experiments aim to characterize our model by behavioural pharmacology in paradigms of anxiety.

\section{Acknowledgements}

Financial support by the NFN-project SI0203-BI3 of the Austrian Science Fund is gratefully acknowledged.

\section{References}

I. Wulff P, Goetz T, Leppä E, Linden AM, Renzi M, Swinny JD, Vekovischeva OY, Sieghart W, Somogyi P, Korpi ER, Farrant M, Wisden $W$ : From synapse to behavior: rapid modulation of defined neuronal types with engineered $\mathbf{G A B A}_{\mathbf{A}}$ receptors. Nature Neurosci 2007, I 0:923-929. 